\title{
Rabies: An Important Zoonotic Disease with Special Reference Knowledge of Dog Owners, Gujarat, India
}

\author{
Heli S. Raval ${ }^{1}$, Jitendra B. Nayak ${ }^{2}$ and Narendrasinh B. Chauhan ${ }^{3}$ \\ ${ }^{1}$ Veterinary and Animal Husbandry Extension, ${ }^{2}$ Department of Veterinary Public \\ Health, ${ }^{3}$ Department of Extension, BACA, AAU, Anand, India \\ India College of Veterinary Science \& Animal Husbandry, Anand Agricultural \\ University, Anand-388001, Gujarat, India \\ *Corresponding author
}

\section{A B S T R A C T}

\section{Keywords}

Rabies, Knowledge level, Dog-owners, Urban area, Gujarat

Article Info

Accepted:

12 January 2019

Available Online:

10 February 2019
Rabies has terrified men since antiquity. Present study was carried out from randomly selected population of 120 dog- owner respondents from 3 urbancities of Gujarat state (India), viz., Ahmadabad, Anand and Vadodarato report percentage analysis of dog-owners on their knowledge level for prevention of rabies in dogs. Highest percentage $(94.16 \%)$ of respondents possessed knowledge about rabies to animals can be caused by bite of rabid dog while lowest percentage of respondents $(40.00 \%)$ were aware about the celebration of the world rabies day. Details of the survey have been mentioned in this research note. The data would provide new insights to know present status and to create awareness in urban areas of Gujaratstate regarding this potential zoonotic disease.

\section{Introduction}

The word "Rabies" has come from the Sanskrit word "RABHAS" MEANS "To make Violence". Rabies is a zoonotic disease that is caused by virus. Human Rabies is endemic throughout the main land of India and only the islands of Andaman \& Nicobar and Lakshadweep are rabies free. The annual incidence of human rabies death is estimated at 20,000 deaths every year. Almost one million people in India annually receive post exposure treatment (PET) against rabies. The dog population is now estimated to be around
27 million. One survey has estimated 2.28 million animal bites per year in India. The principal reservoir is the dog (96.30 per cent). The disease is transmitted to domestic animals and human through exposure to infected saliva.

The use of rabies vaccine in India is very low and that of rabies immunoglobulin's negligible. Present survey was undertaken to assess knowledge level of dog-owners of urban areas of Gujarat state with special reference to rabies, a potential zoonotic diseases. 


\section{Materials and Methods}

The present research was carried out in order to evaluate present status of knowledge level of dog-owners of 3 urban cities, viz., Ahmedabad, Anand and Vadodara of Gujarat state (India) between August-2014 to March2015. For this purpose, a total of 120 randomly selected dog-owners (respondents) were subjected to direct interview. Interview questionnaire included basic aspects of rabies in dogs. The aim of the study was to report a baseline information of urban dog-owners' knowledge on potential zoonotic importance of rabies which would be helpful in expansion of awareness campaigns.

\section{Results and Discussion}

Percentage analysis of dog-owners' knowledge has been shown in Table 1. Loss of appetite in dogs is a common clinical sign associate with a wide variety of infectious as well as non-infectious diseases. In the present study, it was indicated that overwhelming majority (94.16 per cent) of dog owners had knowledge that rabies to animals can be caused by bite of rabid dog. Whereas, 80.00 per cent dog owners known that rabies virus present in saliva of dogs. But only 75.00 per cent dog owners had knowledge about rabies caused by Lyssa virus. These findings are in correlation with criteria suggested by Fontaine and Schantz (1988). A common route for transmission of rabies in humans is direct or indirect contact with tissues contaminated with dog's saliva. Only 62.50 per cent dog owners had knowledge that children are more prone to rabies. Only 66.66 per cent of the dog owners were aware about there are two forms of Rabies. (I) Dum (II) Furious and rabies vaccine must be given annually to pet dog. Whereas vast majority (77.50 per cent) of them were known about the symptoms of rabies like profuse salivation, depression and convulsions. In addition to that, more than three-fourth (75.83 per cent) had realized that rabies to dog owners can be caused by contact of bruised or injured body part with saliva of rabid dogs. Similar reasons were reported by Bingham et al., (2010) for reduced level of knowledge among dog-owners on potential zoonotic risks from diseases of dogs majority (74.16 per cent) of dog owners had knowledge regarding the symptoms in man like salivation, excitement, dysphasia and convulsion. Among all the dog owners very less 40.00 per cent of the dog owners had information about world rabies day celebration on $28^{\text {th }}$ September. Slightly more than half 60.83 per cent dog owners were aware about that full course of rabies vaccine after dog bite should be taken. Less numbers of respondents in this category can be due to low level of massmedia exposure for creating awareness against potential hazards of zoonotic diseases from dogs (Stull et al., 2012; Bhadesiya and Raval, 2014).

A veterinarian also plays an important role in order to establish one health concept (Grant and Osten, 1999). Rabies is equally harmful to humans as to dogs. The details on zoonotic importance of rabies interms of percentage analysis would provide new insights for research, therapeutic and preventive trials as well as implementation of awareness campaigns by both, human and veterinary medicine practitioners. It is revealed that vast majority of the dog owners had knowledge about rabies. The prophylactic immunization of dogs in one of the most important method for rabies control. This will to help reduce need of post expose vaccination of humans to a great extent. The strategy required to enhance awareness regarding timely and appropriate post-exposure treatment, training health professionals, ensure availability of vaccine and antisera and strengthen diagnostic capabilities. 
Table.1 Distribution of the dog owners according to their knowledge about rabies $(\mathrm{N}=120)$

\begin{tabular}{|c|c|c|c|}
\hline $\begin{array}{l}\text { Sr. } \\
\text { No. }\end{array}$ & Awareness of dog-owners' about... & $\begin{array}{l}\text { No. } \\
\text { of }\end{array}$ & $\begin{array}{l}\text { Percenta } \\
\text { ge }\end{array}$ \\
\hline 1 & Rabies to animals can be caused by bite of rabid dog & 113 & 94.16 \\
\hline 2 & Rabies virus present in the saliva of dog. & 96 & 80.00 \\
\hline 3 & Rabies caused by Lyssa virus. & 90 & 75.00 \\
\hline 4 & Children are more prone to rabies. & 75 & 62.50 \\
\hline 5 & There are two forms of Rabies. (I) Dum (II) Furious & 80 & 66.66 \\
\hline 6 & $\begin{array}{l}\text { Rabies in man causes salivation, excitement, } \\
\text { dysphagia, hydrophobia and convulsions }\end{array}$ & 89 & 74.16 \\
\hline 7 & $\begin{array}{l}\text { Rabies in dog causes profuse salivation, depression } \\
\text { and convulsions }\end{array}$ & 93 & 77.50 \\
\hline 8 & $\begin{array}{l}\text { Rabies to dog owners can be caused by contact of } \\
\text { bruised or injured body part with saliva of rabid dogs }\end{array}$ & 91 & 75.83 \\
\hline 9 & Rabies vaccine must be given annually to pet dog. & 80 & 66.66 \\
\hline 10 & $\begin{array}{l}\text { World Rabies day is celebrated on the } 28^{\text {th }} \text { September } \\
\text { every year. }\end{array}$ & 48 & 40.00 \\
\hline 11 & $\begin{array}{l}\text { Full course of rabies vaccine after dog bite should be } \\
\text { taken. }\end{array}$ & 73 & 60.83 \\
\hline
\end{tabular}

\section{References}

Bhadesiya, C.M. and Raval, S.K.(2014). Percentage analysis of knowledge level for dog-ownership in rural areas of Gujarat. International Journal of Social Science \& Humanities Research, 2(4): 300-302.

Bingham, G.M., Budke, C.M. and Slater, M.R. (2010). Knowledge and perception of dog associated zoonoses Brazos Country, Texas, USA. Preventive Vet. Med., 93: 211-221.

Fontaine, R.E. and Schantz, P.M. (1988). Pet ownership and knowledge of zoonotic diseases in Dekalk county Georgia. Anthrozoos, 3:45-49

Grant, S. and Otsen, C.W. (1999). Preventing zoonotic diseases in immunocompromised persons: The role of physician and veterinarians. Emerg. Infect. Dis., 5:159-163

Stull, J.W., Peregrine, A.S., Sargeant, J.M. and Weese, J.S. (2012). Household knowledge, attitudes and practices related to pet contact and associated zoonoses in Ontario, Canada. $B M C$ Public Health, 12: 553.

\section{How to cite this article:}

Heli S. Raval, Jitendra B. Nayak and Narendrasinh B. Chauhan. 2019. Rabies: An Important Zoonotic Disease with Special Reference Knowledge of Dog Owners, Gujarat, India. Int.J.Curr.Microbiol.App.Sci. 8(02): 1622-1624. doi: https://doi.org/10.20546/ijcmas.2019.802.190 